\title{
Sistem Pengawasan Operasional Pada Angkuran Publik Trans SARBAGITA
}

\author{
Putu Arya Hening Tryasthana, Ni Made Ika Marini Mandenni, Ni Kadek Ayu Wirdiani \\ Program Studi Teknologi Informasi, Fakultas Teknik, Universitas Udayana \\ Bukit Jimbaran, Bali, Indonesia, 80361, telp.: (0361) 701806 \\ E-mail: tryasthana@gmail.com, made.ika.mm@gmail.com, ayu wirdi@yahoo.com
}

\begin{abstract}
Abstrak
Moda transportasi yang terjadwal dibutuhkan masyarakat, UPT Trans SARBAGITA Dinas Perhubungan Provinsi Bali dituntut untuk meningkatkan kualitas layanan sehingga kegiatan operasional Trans SARBAGITA berjalan secara efektif. Kurang sesuainya interval waktu keberangkatan yang mengakibatkan penumpukan penumpang di halte menjadi tantangan bagi petugas kendali untuk mengatur waktu agar tidak ada lagi penumpukan penumpang pada setiap halte. Kegiatan operasional yang efektif akan terwujud dengan adanya sistem yang dapat mempermudah petugas admin, kendali, pengawas, pramujasa dan pramudi. Sistem pengawasan operasional pada angkutan publik Trans SARBAGITA merupakan sistem yang digunakan untuk proses pengawasan terkait dengan input informasi bus seperti resgistrasi bus, lokasi pos atau halte, data kilometer tempuh operasional, keberadaan, kedatangan, keberangkatan, dan status bus. Hasil input data yang dilakukan memudahkan petugas kendali dalam mengawasi terkait operasional bus Trans SARBAGITA, sehingga kegiatan operasional bus Trans SARBAGITA dilakukan dengan efektif dan dapat mewujudkan moda transportasi publik yang terjadwal lebih baik.
\end{abstract}

Kata Kunci: Transportasi Publik, Operasional Bus, UPT Trans SARBAGITA, Pengawasan Operasional

\begin{abstract}
Scheduled modes of transportation are needed for the society; as a result, the UPT Trans SARBAGITA Transportation Agency of Bali Province are demanded to improve the operational effectiveness and quality of services. Due to lack of conformity in departure time interval, buildup of passengers at the bus stop is being a challenge for the control officer to set the time so that in the future there's no more cumulation at each stop. An effective operational activity will be realized with the existence of a system that can facilitate admin officers, controllers, supervisors, bus drivers and bus ticket takers. The operational supervision system of public transportation, Trans SARBAGITA is a system used for the supervisory process related to bus information input such as bus administration, postal location or bus stop, operational mileage data, presence, arrival, departure, and bus status. The results of the data input which has done make it easier for control officers to supervise the operation of the Trans SARBAGITA bus; thus, the SARBAGITA Trans bus operational activities were conducted effectively and could realize a better scheduled public transportation modes.
\end{abstract}

Keywords: Public Transportation, Bus Operations, UPT Trans SARBAGITA, Operational Supervision

\section{Pendahuluan}

Pemerintah telah mengembangkan beberapa fasilitas transportasi salah satunya adalah fasilitas angkutan umum bus. Angkutan umum memiliki peranan yang penting bagi sebagian besar masyarakat, namun dalam kegiatan operasionalnya masih terdapat masalah. Penumpang sering menghadapi masalah dalam memutuskan trasportasi yang lebih cepat antara bus dan angkutan umum lainnya [1]. Operasional sehari-hari sistem transportasi umum terutama bus dipengaruhi oleh berbagai kondisi yang tidak menentu seperti kemacetan lalu lintas, keterlambatan yang tidak terduga, permintaan penumpang yang sewaktu-waktu meningkat di beberapa halte, waktu pengiriman kendaraan yang tidak teratur dan insiden. 
Keadaan ini tentu berdampak secara langsung ataupun tidak langsung bagi penumpang yang memutuskan untuk menggunakan transportasi umum. GPS dan jaringan seluler memungkinkan pelacakan kendaraan secara realtime untuk manajemen transportasi yang lebih baik. Teknologi ini dapat diterapkan pada sistem transportasi umum, terutama bus, yang tidak dapat mematuhi jadwal yang telah ditentukan karena alasan seperti kemacetan lalu lintas dan kerusakan pada bus [2].

Penggunaan lokasi geografi membuat pengguna sistem dapat mengumpulkan informasi yang dibutuhkan ketika menggunakan perangkat seluler. Location based service (LBS) merupakan salah satu jenis layanan untuk membantu memperoleh informasi terkait lokasi geografi pengguna sistem dan informasi penting lainnya yang ada disekitar pengguna seperti posisi, jarak, rute dan lain-lain [3]. Location Based Service menyediakan informasi yang dapat diakses di perangkat seluler melalui jaringan seluler dan juga memberikan informasi tentang posisi geografis perangkat seluler. Pemrosesan query pengguna dapat mengambil lokasi saat ini sehingga pengguna tidak perlu membawa personal computer (PC) sepanjang perjalanan untuk mengambil detail lokasi tujuan, karena dengan megunakan perangkat seluler yang terintegrasi dengan Google Maps, penyedia jaringan dan GPS untuk mengambil nilai garis lintang dan garis bujur. Layanan Berbasis Lokasi menggunakan GPS untuk mencari lokasi pengguna serta pengguna dapat memilih tujuan baru dari minat mereka [4].

Sistem Informasi Geografis (SIG) merupakan sistem infomasi berbasis komputer yang merupakan penggabungan antara unsur peta (geografis) dan informasi tentang peta tersebut (data atribut), yang dirancang untuk mendapatkan, mengolah, memanipulasi, analisis, memperagakan dan menampilkan data spasial untuk menyelesaikan perencanaan, mengolah dan meneliti permasalahan [5]. Komponen utama SIG adalah sistem komputer, data spasial dan pengguna. Sistem komputer untuk SIG terdiri dari perangkat keras, perangkat lunak dan prosedur yang dirancang untuk mendukung entri data, pengolahan, analisis, pemodelan dan tampilan data geospasial [6]. Penelitian tentang sistem informasi geografis pernah dibahas dalam penelitian berjudul "Sistem Informasi Geografis Pemetaan Jalan Desa Berbasis Web", penggunaan fitur polyline dalam Google Maps mampu menggambarkan sebuah jaringan jalan dan Geometry Library untuk menghitung panjang jalan, yang dapat memberikan informasi bagi pengguna tentang nama jalan, panjang jalan, jenis permukaan jalan dan kondisi jalan [7]. Penelitian yang berjudul "Sistem Informasi Geografis Pemetaan Daerah Aliran Sungai Berbasis Web" juga menggunakan Google Maps. Sistem ini melakukan pendataan daerah aliran sungai dengan dua cara, yaitu digitasi dan input koordinat yang dilakukan oleh admin. Hasil dari pendataan data aliran sungai dapat memberikan informasi bagi pengguna tentang lokasi bendungan beserta deskripsinya, jaringan sungai dalam daerah aliran sungai, titik rawan banjir, panjang genangan banjir dan batas dari daerah aliran sungai beserta deskripsinya [8].

Penelitian tentang Trans SARBAGITA pernah dibahas dalam penelitian berjudul " $E$ Tracking Trans Bus Information System". Fitur yang dimiliki E-Tracking adalah sebagai berikut: member (penumpang) meliliki fitur check in halte, show bus dan track bus (pantau bus). Operator memiliki fitur set route, post information, show check in dan clear check in. Admin memiliki fitur monitoring check in dan bus. Penetilian ini berfokus pada tracking bus untuk memberikan infomasi kepada pengguna bus Trans SARBAGITA [9].

Penelitian "E-Tracking Trans Bus Information System" lebih berfokus pada perancangan rute bus Trans SARBAGITA dalam bentuk peta digital, E-tracking bus Trans SARBAGITA untuk memberikan informasi kepada pengguna bus, dan E-tiketing Trans SARBAGITA untuk manajemen ticketing bus. Penelitian "E-Tracking Trans Bus Information System" belum memberikan solusi untuk pengawasan operasional Trans SARBAGITA, maka timbul pemikiran dalam membuat rancang bangun "Sistem Pengawasan Operasional pada Angkutan Publik Trans SARBAGITA" yang akan menjadi solusi dalam proses mempermudah pengawasan operasional serta pengambilan keputusan petugas kendali bus Trans SARBAGITA. Petugas kendali akan mendapatkan data waktu tiba bus, waktu berangkat bus, status bus dan posisi bus. Petugas pengawas memasukan data waktu tiba bus, waktu berangkat bus dan status bus pada sistem pengawasan operasional. Pramudi memberikan data lokasi bus melalui aplikasi mobile Android. Sistem Pengawasan Operasional memberikan informasi yang tepat kepada petugas kendali maka akan mempermudah petugas kendali dalam pengawasan serta penyesuaian interval waktu pelepasan bus Trans SARBAGITA. 


\section{Metode dan Perancangan Sistem}

\subsection{Rancangan Umum Sistem}

Gambaran umum sistem pengawasan operasional pada angkutan publik Trans SARBAGITA memiliki dua buah jalur akses mobile platform android dan web. Petugas lapangan (pramujasa dan pengawas) melakukan input ke sistem melalui smartphone (mobile platform).

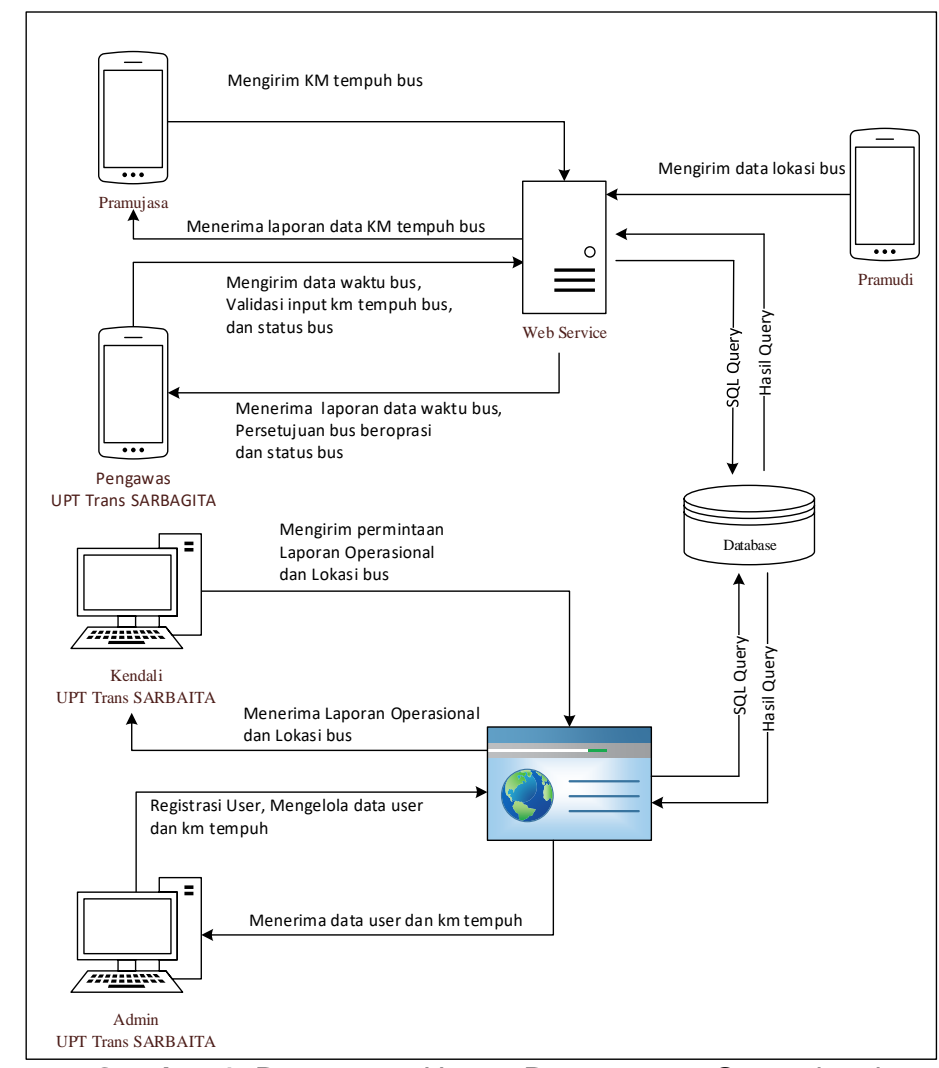

Gambar 1. Rancangan Umum Pengawasan Operasional

Gambar 1 menunjukan petugas kendali dan admin melakukan input melalui web. Pramujasa melakukan input kilometer operasional bus dari awal pool sampai operasi berakhir. Pramudi mengirimkan data lokasi bus dari awal pool sampai operasi berakhir. Pengawas melakukan input waktu tiba dan berangkat bus Trans SARBAGITA dari pos dimana pengawas tersebut bertugas. Kendali memonitor operasional bus Trans SARBAGITA melalui laporan lokasi bus serta waktu tiba dan berangkat bus. Admin melakukan manajemen data user, data bus dan data kilometer operasional.

\section{Kajian Pustaka}

\subsection{Trans SARBAGITA}

Trans SARBAGITA adalah Bus Rapid Transit (BRT). Sistem ini mulai beroperasi pada 18 Agustus 2011. Di desain untuk membangun kembali system transportasi public Bali. Koridor I Denpasar Kota-Garuda Wisnu Kencana PP yang di operasionalkan oleh Perum Damri dengan harga tiket adalah Rp 3.500 untuk dewasa dan Rp 2.500 untuk pelajar. Koridor II BatubulanNusa Dua PP yang di operasionalkan oleh Perum Damri dengan harga tiket adalah Rp 3.500 untuk dewasa dan Rp 2.500 untuk pelajar. UPT. Trans SARBAGITA sebagai pengawas operasional Trans SARBAGITA. Petugas kendali berkoordinasi dengan pengawas yang berada di masing-masing pos awal dan akhir operasional untuk mengawasi operasional Trans SARBAGITA [10].

\subsubsection{Rute Trans SARBAGITA}

Trans SARBAGITA memiliki dua koridor yang beroperasi yakni koridor I Trayek GOR Ngurah Rai-GWK PP dan koridor II Trayek Batubulan-Nusa Dua PP. Rute dari masing-masing koridor tersebut yaitu: 
1. Koridor I Trayek GOR Ngurah Rai-GWK PP

Halte Gor Lila Bhuan-SMAN 7 (Jl. Kamboja)-Jl. Angsoka-Melati-Surapati Kapten Agung Letda Made Putra-Jl. PB Sudirman-Waturenggong-Diponegoro-Raya Sesetan-Bypass Ngurah Rai-Dewa Ruci-Bypass Nusa Dua-Jl. Udayana/Kampus UNUD Bukit-Jl. UluwatuHalte GWK

Halte GWK-Raya Uluwatu-Jl.Udayana Kampus Bukit-Bypass Nusadua-Dewa RuciPesanggaran-Raya Sesetan-Diponegoro-Serma Durna-Serma Made Pil-Serma Mendra-PB Sudirman-Dewi Sartika-Diponegoro Hasannudin-JI. Udayana Surapati-Kamboja-AngsokaMelati-Patimura-Halte Gor Lila Bhuana

2. Koridor II Trayek Batubulan - Nusa Dua PP

Terminal Batubulan-WR Supratman-JI. Bypass Ngurah Rai-JI.Prof I.B Mantera-Jl. Bypass Ngurah Rai-Simpang Dewa Ruci-JI.Setiabudi Kuta-JI.Raya Kuta-Sentral Parkir KutaJl. Imam Bonjol-Jl.Sunset Road Timur-Simpang Dewa Ruci-Jl.Bypass Nusa Dua-Jl. Masuk Kawasan Nusadua-JI. Amphi Halte BTDC 1

Halte BTDC 1-JI Bali Int Lawn Bowling-Jl.Kawasan Nusadua Resort (Halte BTD2)-JI Tg Benoa Bualu-JI. Bypass Nusadua-Simpang Dewa Ruci-Jl. Setiabudi Kuta-Jl.Raya KutaSentral Parkir Kuta-Jl.Imam Bonjol-Jl.Sunset Road Timur-Simpang Dewa Ruci-Jl.Bypass Ngurah Rai-JI.WR Supratman-JI. Raya Batubulan-JI. Batuyang Terminal Batubulan [10].

\subsection{Google Maps}

Google Maps diluncurkan pada tahun 2005 telah merevolusi aplikasi layanan pemetaan online di World Wide Web, dengan berbasis JavaScript dan XML (AJAX) menggunakan tipe interaksi client-server diperkenalkan Google Maps untuk mempertahankan hubungan yang berkelanjutan antara client-server untuk mengunduh langsung informasi dari peta. Google Maps saat ini banyak digunakan sebagai Online Application untuk memetakan sebuah titik, jaringan ataupun sebuah daerah yang dibangun sebagai Sistem Informasi Geografis [7].

\section{Hasil dan Pembahasan}

4.1 Pengawasan Operasional

Halaman pegnawas merupakan halaman khusus untuk user yang memiliki jabatan sebagai pengawas. Pengawas dapat melakukan input waktu tiba, berangkat, status bus, dan token.

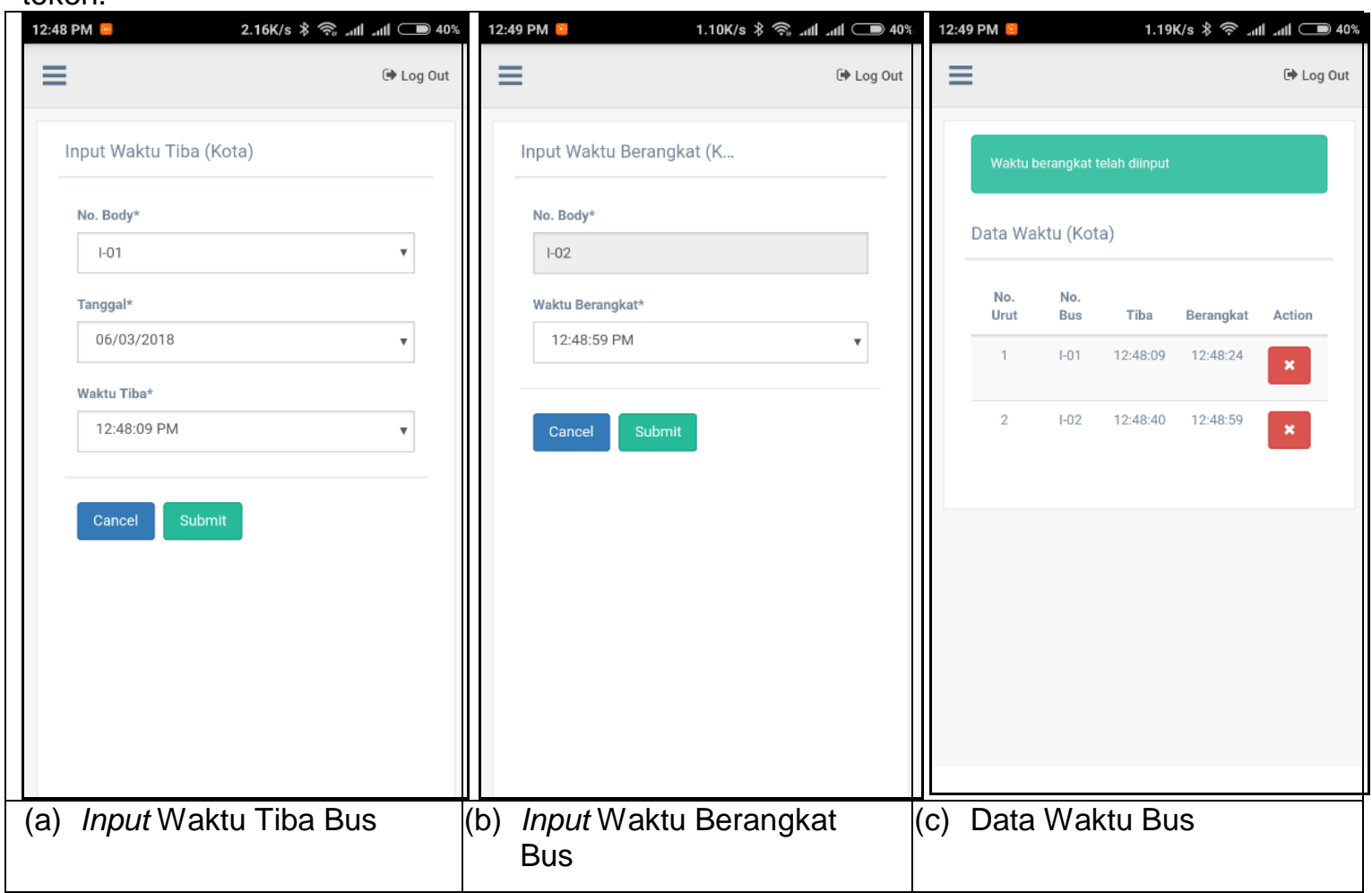

Gambar 2. Manajemen Waktu 
Gambar 2 menunjukan fitur untuk input waktu tiba bus, waktu berangkat bus, dan melihat data waktu bus. Halaman manajemen waktu menampilkan data waktu yang dibutuhkan oleh petugas kendali untuk mengetahui interval waktu keberangkatan dan waktu tiba bus Trans SARBAGITA.

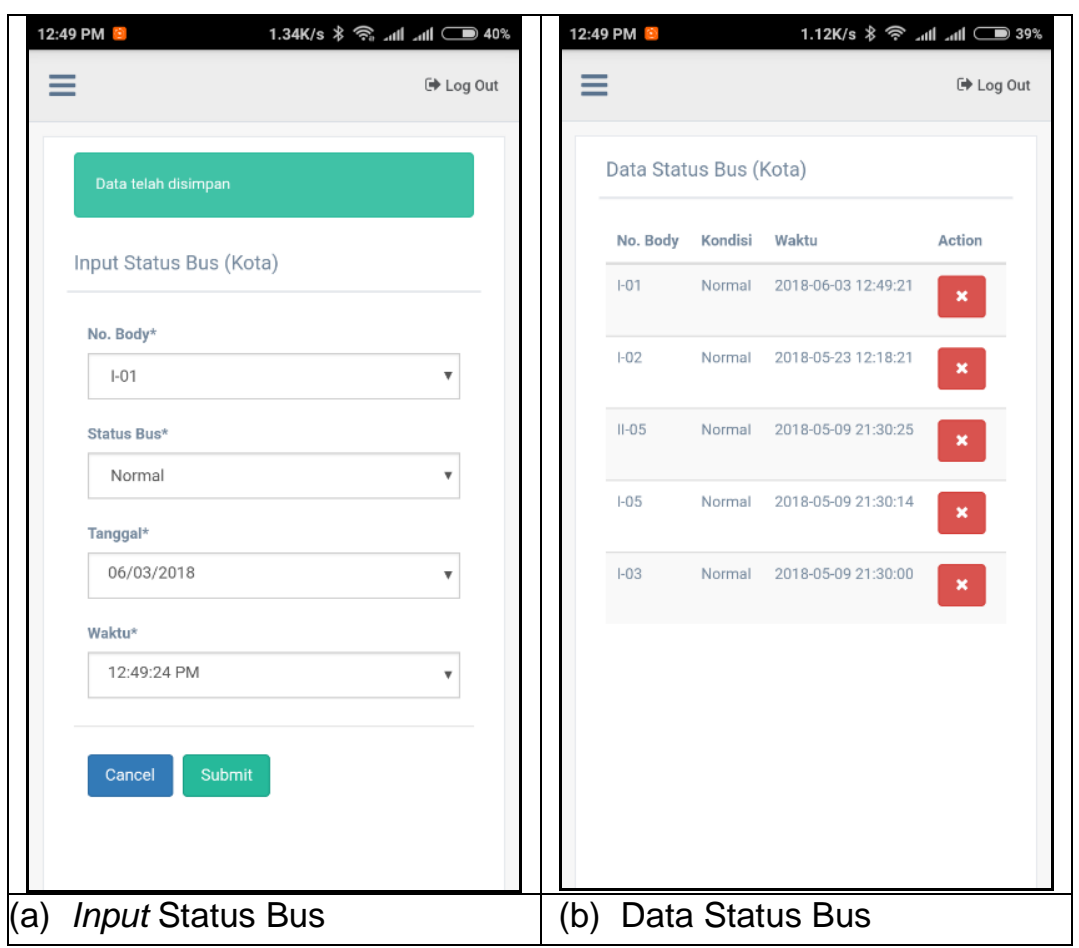

Gambar 3. Manajemen Status Bus

Gambar 3 menunjukan fitur untuk input status bus dan melihat data status bus yang di input oleh pengawas. Halaman manajemen status bus menampilkan kondisi bus yang beroperasi, yang dibutuhkan kendali untuk penyesuaian interval keberangkatan bus.

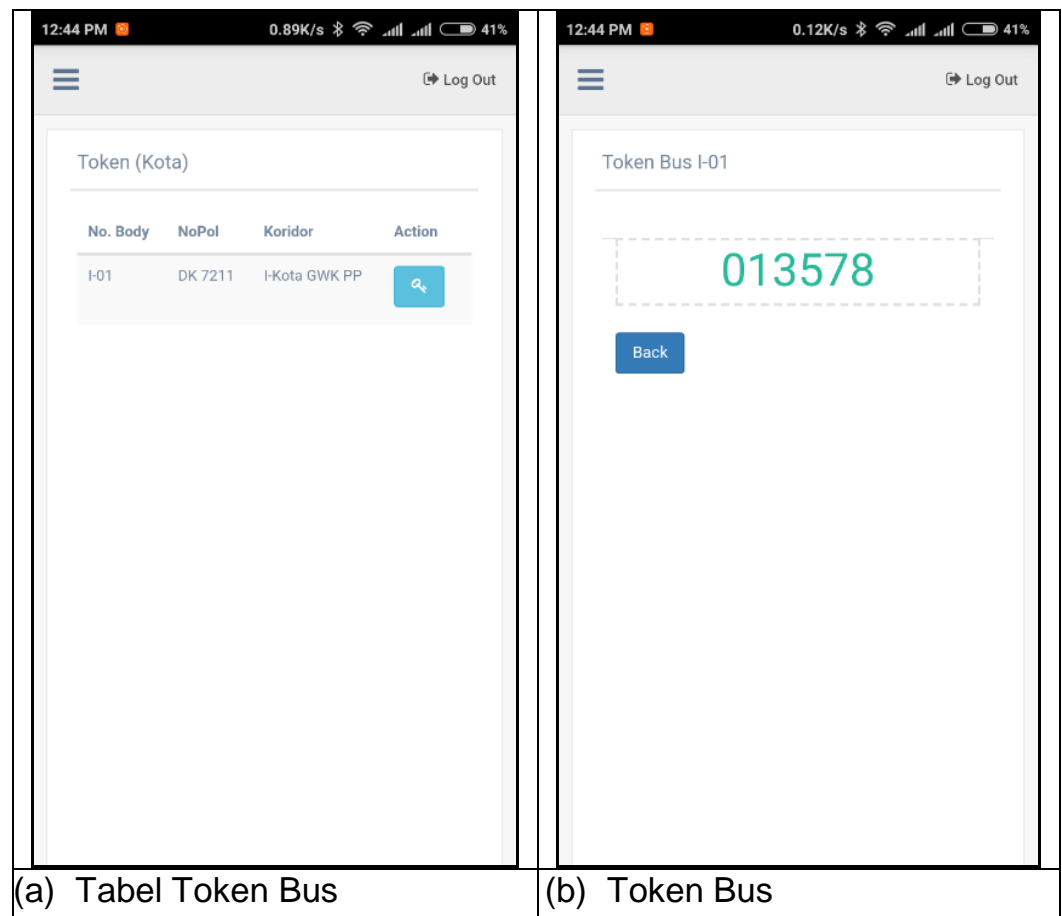

Gambar 4. Manajemen Status Bus 
Gambar 4 menunjukan fitur untuk membuat token bus dan melihat data token bus. Petugas pengawas di lapangan meberikan token bus kepada pramujasa sebagai validasi untuk input kilometer awal operasi dan akhir operasi.

\subsection{Pencatatan Kilometer Bus}

Halaman pramujasa merupakan halaman khusus untuk user yang memiliki jabatan sebagai pramujasa. Pramujasa dapat melakukan input kilometer pool, operasi awal, operasi akhir, dan melihat data kilometer akhir.

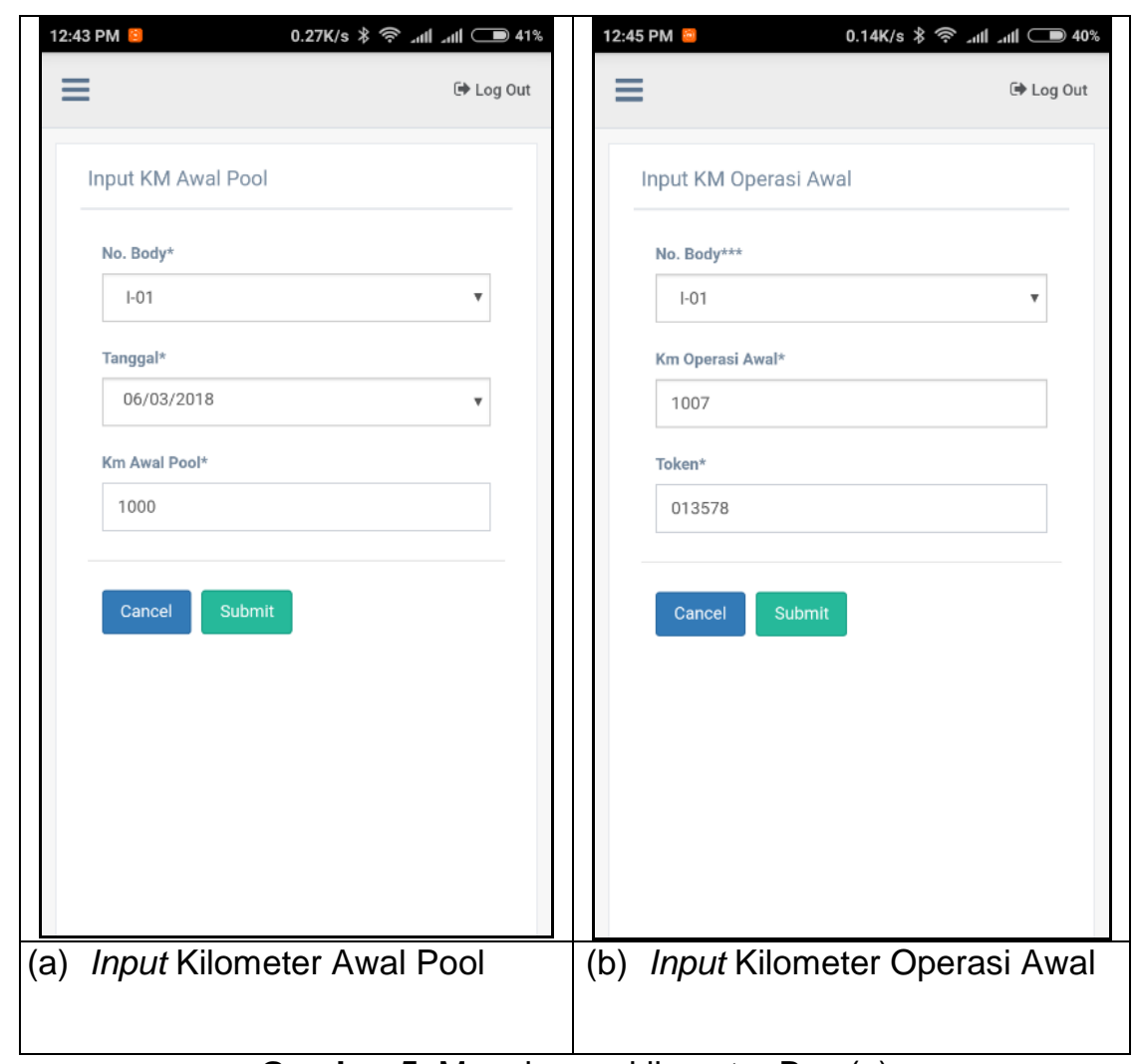

Gambar 5. Manajemen kilometer Bus (a)

Gambar 5 menunjukan fitur untuk input kilometer awal pool dan kilometer operasi awal bus. Petugas pramujasa melakukan melakukan input kilometer awal pool pada saat di pool bus. Input kilometer operasi awal dilakukan pramujasa sebelum keberangkatan awal bus. Pramujasa dapat melakukan input kilometer jika telah memasukan token yang telah diberikan oleh pengawas. Petugas pengawas bertanggung jawab atas keakuratan data kilometer. 


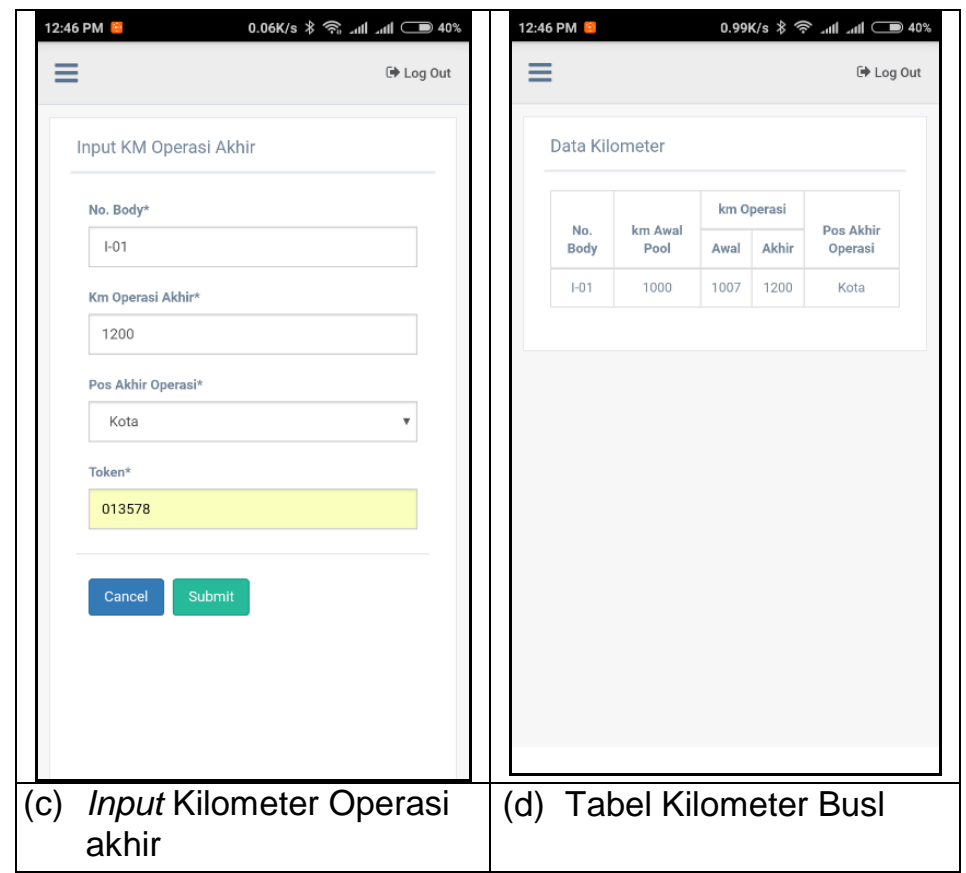

Gambar 6. Manajemen kilometer Bus (b)

Gambar 6 menunjukan fitur untuk input kilometer operasi akhir dan tabel kilometer bus. Petugas pramujasa melakukan melakukan input kilometer akhir operasi pada saat operasional bus berakhir. Pramujasa dapat melakukan input kilometer jika telah memasukan token yang telah diberikan oleh pengawas. Petugas pengawas bertanggung jawab atas keakuratan data kilometer.

\subsection{Tracking Bus}

Halaman pramudi merupakan halaman khusus untuk user pramudi melakukan login dan sistem memulai proses tracking bus.

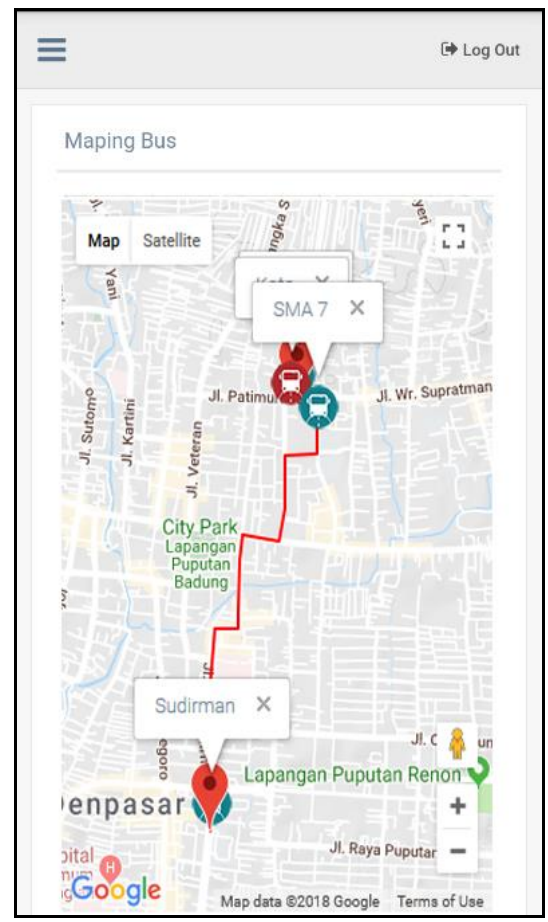

Gambar 7. Tracking Bus 
Gambar 7 menunjukan fitur untuk tracking bus. Pengujian sistem pada Koridor I GOR Ngurah Rai-GWK PP marker akan terus bergerak sesuai pergerakan bus dari posisi awal halte GOR hingga posisi terakhir di halte Sudirman.

\subsection{Kendali}

Halaman Kendali merupakan halaman khusus untuk user yang memiliki jabatan sebagai kendali. Fitur yang dimiliki memudahkan petugas kendali dalam mendapatkan informasi posisi bus melalui tracking GPS, waktu tempuh bus dan status bus.

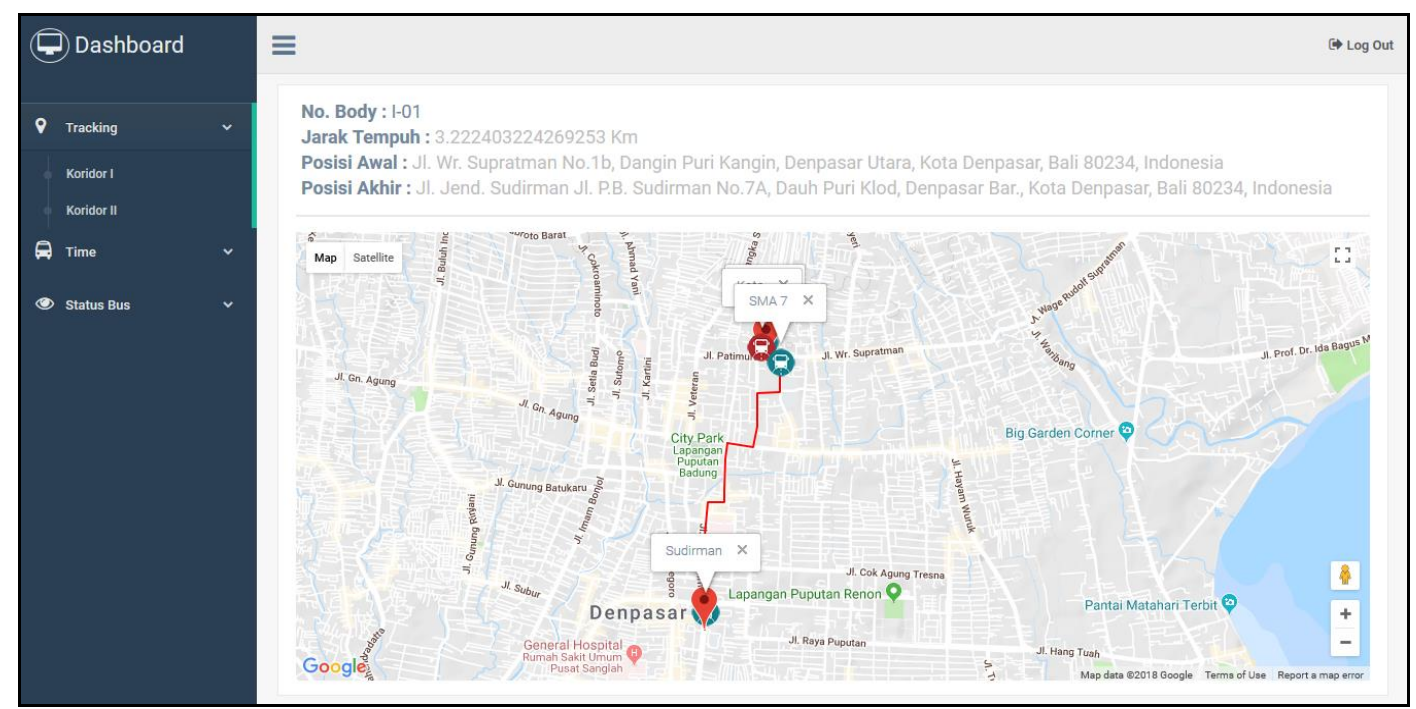

Gambar 8. Tracking Bus

Gambar 8 menampilkan tracking bus dalam bentuk google map yang didapatkan dari pramudi melalui aplikasi mobile. Interval update data tracking bus adalah berdasarkan radius 500 meter. Marker akan berpindah jika bus telah menempuh 500 meter. Posisi akhir bus dalam bentuk alamat merupakan hasil konversi dari koordinat bus dari Google Map API. Jarak tempuh bus yang ditampilkan merupakan hasil dari perhitungan polyline bus yang di konversi dari koordinat-koordinat bus dari Google Map Api. Pos awal dan akhir operasi serta halte di tampilkan pada map berupa icon bus. Icon bus berwarna merah merupakan pos awal dan akhir operasi sedangkan icon bus berwana biru merupakan halte bus.

Pengujian sistem pada Koridor I GOR Ngurah Rai-GWK PP menunjukan pergerakan bus dari posisi awal halte GOR hingga posisi terakhir di halte Sudirman. Selain mengetahui posisi bus, petugas kendali juga dapat mengetahui jarak tempuh bus dari posisi awal bus hingga posisi akhir bus. Informasi yang didapatkan oleh kendali dapat dijadikan acuan pengambilan keputusan agar tidak terjadi penumpukan bus.

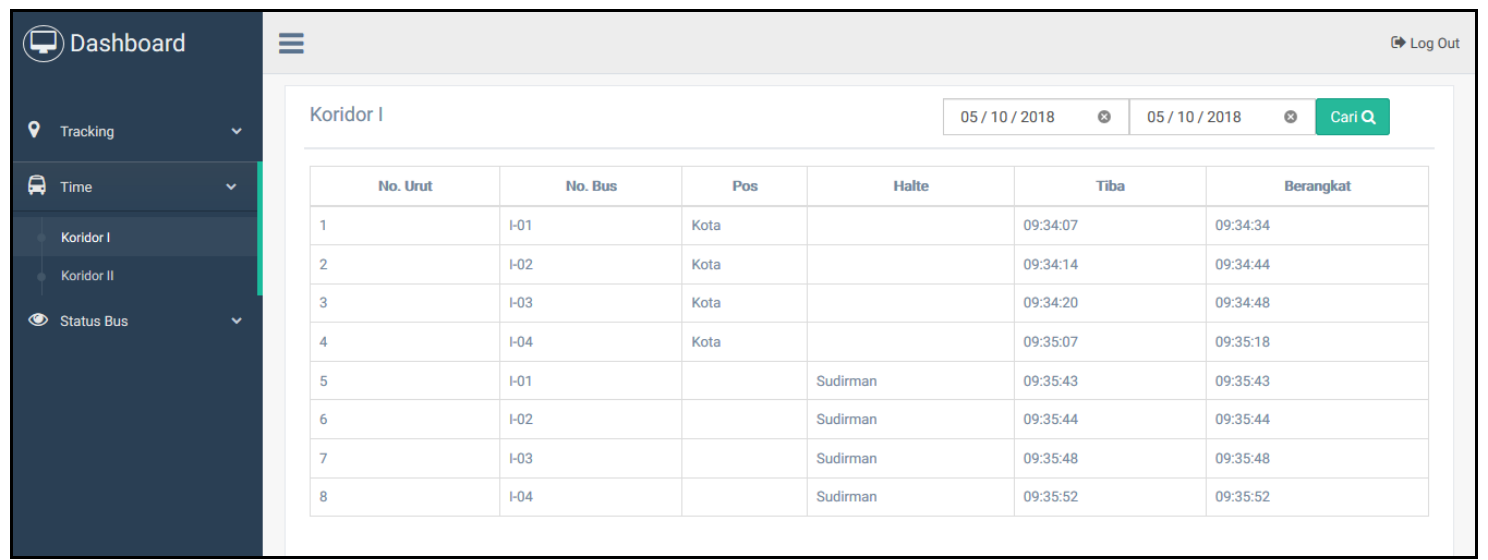

Gambar 9. Waktu Tempuh Bus 
Gambar 9 menampilkan data waktu bus yang diperoleh dari hasil input petugas pengawas melalui aplikasi mobile. Halaman waktu tempuh bus menampilkan nomor bus, waktu tiba dan berangkat. Sehingga petugas kendali dapat mengetahui waktu tiba dan waktu berangkat bus.

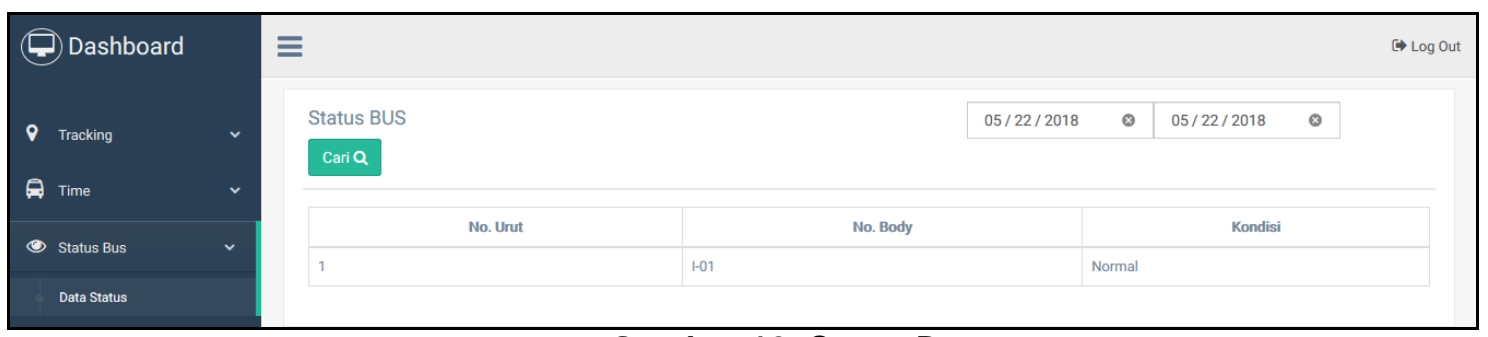

Gambar 10. Status Bus

Gambar 10 menampilkan data status bus. Halaman status bus menampilkan terkait dengan kondisi bus. Kondisi bus yang dimaksud yaitu bus dalam kondisi normal atau bus dalam kondisi pemeliharaan (air conditioner, mesin, lampu dan ban). Sehingga bila dalam waktu operasional bus terdapat bus yang kondisinya tidak normal, petugas kendali dengan pengawas dapat segera berkoordinasi untuk memutuskan keputusan yang tepat sehingga tidak menghambat operasional bus.

\subsection{Pengujian Black Box}

Black Box Testing merupakan suatu bentuk pengujian yang menggunakan metode pengujian yang menguji fungsionalitas aplikasi. Hasil pengujian black box pada sistem pengawasan operasional pada angkutan publik Trans SARBAGITA adalah sebagai berikut:

Table 1. Tabel Pengujian Black Box Pengawasan Operasional

\begin{tabular}{|c|c|c|c|}
\hline No & $\begin{array}{c}\text { Nama } \\
\text { Pengujian }\end{array}$ & Kondisi Pengujian & Hasil Pengujian \\
\hline 1 & $\begin{array}{l}\text { Input Waktu } \\
\text { Tiba Bus }\end{array}$ & $\begin{array}{l}\text { Pengawas memasukan } \\
\text { data no. body bus }\end{array}$ & $\begin{array}{l}\text { Sistem menampilkan peringatan "Data } \\
\text { Berhasil Disimpan" saat menekan } \\
\text { tombol simpan, jika pengawas sudah } \\
\text { memasukan data yang valid, jika } \\
\text { kolom tidak diisi maka muncul pesan } \\
\text { kesalahan "please fill out this field". }\end{array}$ \\
\hline 2 & $\begin{array}{l}\text { Input Waktu } \\
\text { Berangkat Bus }\end{array}$ & $\begin{array}{l}\text { Pengawas memasukan } \\
\text { data no. body bus }\end{array}$ & $\begin{array}{l}\text { Sistem menampilkan peringatan "Data } \\
\text { Berhasil Disimpan" saat menekan } \\
\text { tombol simpan, jika pengawas sudah } \\
\text { memasukan data yang valid, jika } \\
\text { kolom tidak diisi maka muncul pesan } \\
\text { kesalahan "please fill out this field". }\end{array}$ \\
\hline 3 & $\begin{array}{l}\text { Menampilkan } \\
\text { Data Waktu Bus }\end{array}$ & $\begin{array}{l}\text { Pengawas memilih } \\
\text { menu Data Waktu }\end{array}$ & Sistem menampilkan tabel data waktu \\
\hline 4 & $\begin{array}{l}\text { Input Status } \\
\text { Bus }\end{array}$ & $\begin{array}{l}\text { Pengawas memasukan } \\
\text { data no. body bus dan } \\
\text { status bus. }\end{array}$ & $\begin{array}{l}\text { Sistem menampilkan peringatan "Data } \\
\text { Berhasil Disimpan" saat menekan } \\
\text { tombol simpan, jika pengawas sudah } \\
\text { memasukan data yang valid, jika } \\
\text { kolom tidak diisi maka muncul pesan } \\
\text { kesalahan "please fill out this field". }\end{array}$ \\
\hline 5 & $\begin{array}{l}\text { Menampilkan } \\
\text { Data Status Bus }\end{array}$ & $\begin{array}{l}\text { Pengawas memilih } \\
\text { menu Data Status }\end{array}$ & Sistem menampilkan tabel data status \\
\hline 6 & Membuat token & $\begin{array}{l}\text { Pengawas memilih } \\
\text { menu Token dan } \\
\text { memilih tombol token } \\
\text { sesuai dengan bus yang } \\
\text { akan dibuatkan token }\end{array}$ & Sistem menampilkan Token bus \\
\hline
\end{tabular}


Tabel 1 menampilkan pengujian black box pada pengawasan operasional. Pengujian ini dimulai dengan input waktu tiba bus, input waktu berangkat bus, input status bus dan membuat token untuk validasi input data kilometer bus.

Table 2. Tabel Pengujian Black Box Pencatatan Kilometer Bus

\begin{tabular}{|c|c|c|c|}
\hline No & Nama Pengujian & Kondisi Pengujian & Hasil Pengujian \\
\hline 1 & $\begin{array}{l}\text { Input Kilometer } \\
\text { Awal Pool Bus }\end{array}$ & $\begin{array}{l}\text { Pramujasa } \\
\text { memasukan data no. } \\
\text { body bus dan } \\
\text { kilometer awal pool }\end{array}$ & $\begin{array}{l}\text { Sistem menampilkan peringatan "Data } \\
\text { Berhasil Disimpan" saat menekan } \\
\text { tombol simpan, jika pramujasa sudah } \\
\text { memasukan data yang valid, jika kolom } \\
\text { tidak diisi maka muncul pesan } \\
\text { kesalahan "Silahkan isi form dengan } \\
\text { benar", jika kolom km awal pool diisi } \\
\text { selain angka maka muncul pesan } \\
\text { kesalahan "Silahkan isi form dengan } \\
\text { benar", dan jika pramujasa melakukan } \\
\text { input kilometer awal pool dua kali maka } \\
\text { muncul pesan kesalahan "Data KM } \\
\text { untuk bus ini telah diinput". }\end{array}$ \\
\hline 2 & $\begin{array}{l}\text { Input } \quad \text { Kilometer } \\
\text { Operasi Awal Bus }\end{array}$ & $\begin{array}{l}\text { Pramujasa } \\
\text { memasukan data no. } \\
\text { body bus, kilometer } \\
\text { operasi awal, dan } \\
\text { token }\end{array}$ & $\begin{array}{l}\text { Sistem menampilkan peringatan "Data } \\
\text { telah disimpan" saat menekan tombol } \\
\text { simpan, jika pramujasa sudah } \\
\text { memasukan data yang valid, jika kolom } \\
\text { tidak diisi maka muncul pesan } \\
\text { kesalahan "Silahkan isi form dengan } \\
\text { benar", jika kolom km operasi awal diisi } \\
\text { selain angka maka muncul pesan } \\
\text { kesalahan "Silahkan isi form dengan } \\
\text { benar", dan jika kolom token tidak valid } \\
\text { maka muncul pesan kesalahan } \\
\text { "Silahkan isi form dengan benar". }\end{array}$ \\
\hline 3 & $\begin{array}{l}\text { Input } \quad \text { Kilometer } \\
\text { Operasi Akhir Bus }\end{array}$ & $\begin{array}{l}\text { Pramujasa } \\
\text { memasukan data no. } \\
\text { body bus, kilometer } \\
\text { operasi akhir, pos } \\
\text { akhir operasi, dan } \\
\text { token }\end{array}$ & $\begin{array}{l}\text { Sistem menampilkan peringatan "Data } \\
\text { telah disimpan" saat menekan tombol } \\
\text { simpan, jika pramujasa sudah } \\
\text { memasukan data yang valid, jika kolom } \\
\text { tidak diisi maka muncul pesan } \\
\text { kesalahan "Silahkan isi form dengan } \\
\text { benar", jika kolom km operasi akhir diisi } \\
\text { selain angka maka muncul pesan } \\
\text { kesalahan "Silahkan isi form dengan } \\
\text { benar", dan jika kolom token tidak valid } \\
\text { maka muncul pesan kesalahan } \\
\text { "Silahkan isi form dengan benar". }\end{array}$ \\
\hline 4 & $\begin{array}{l}\text { Menampilkan Data } \\
\text { Kilometer Akhir }\end{array}$ & $\begin{array}{lr}\text { Pengawas memilih } \\
\text { menu } \\
\text { Kilometer Akhir }\end{array}$ & $\begin{array}{l}\text { Sistem menampilkan tabel data } \\
\text { kilometer akhir }\end{array}$ \\
\hline
\end{tabular}

Tabel 2 menampilkan pengujian black box pada pencatatan kilometer bus. Pengujian ini dimulai dengan input kilometer awal pool bus, Input kilometer operasi awal bus dan input kilometer operasi akhir bus. 
Table 3. Tabel Pengujian Black Box Tracking Bus

\begin{tabular}{|c|c|c|c|}
\hline No & $\begin{array}{c}\text { Nama } \\
\text { Pengujian }\end{array}$ & $\begin{array}{c}\text { Kondisi } \\
\text { Pengujian }\end{array}$ & Hasil Pengujian \\
\hline 1 & $\begin{array}{l}\text { Tracking } \\
\text { Bus }\end{array}$ & $\begin{array}{l}\text { Pramudi } \\
\text { memasukan } \\
\text { data username } \\
\text { dan password }\end{array}$ & $\begin{array}{l}\text { Jika pramudi memasukan username dan password } \\
\text { dengan benar maka, sistem menampilkan posisi } \\
\text { koordinat bus dalam bentuk Google Maps serta } \\
\text { memeriksa jarak lokasi gps titik awal, jika lebih besar } \\
\text { atau sama dengan } 500 \text { meter maka koordinat lokasi bus } \\
\text { di simpan ke database dan jika pramudi memasukan } \\
\text { username dan password yang tidak valid maka muncul } \\
\text { pesan kesalahan "Maaf akun tidak tepat". }\end{array}$ \\
\hline
\end{tabular}

Tabel 3 menampilkan pengujian black box pada tracking bus. Pengujian ini dilakukan pada tracking bus yang dimulai dengan proses login oleh pramudi. Jika proses login sesuai dengan jabatan pramudi, maka sistem menampilkan posisi koordinat bus dalam bentuk Google Maps.

Table 4. Tabel Pengujian Black Box Kendali

\begin{tabular}{|c|c|c|c|}
\hline No & Nama Pengujian & Kondisi Pengujian & Hasil Pengujian \\
\hline 1 & $\begin{array}{l}\text { Menampilkan Data Tracking } \\
\text { Bus Koridor I }\end{array}$ & $\begin{array}{l}\text { Kendali memilih menu } \\
\text { Koridor I }\end{array}$ & $\begin{array}{l}\text { Sistem menampilkan tabel } \\
\text { data tracking koridor I }\end{array}$ \\
\hline 2 & $\begin{array}{l}\text { Menampilkan Data Tracking } \\
\text { Bus Koridor II }\end{array}$ & $\begin{array}{l}\text { Kendali memilih menu } \\
\text { Koridor II }\end{array}$ & $\begin{array}{l}\text { Sistem menampilkan tabel } \\
\text { data tracking koridor II }\end{array}$ \\
\hline 3 & $\begin{array}{l}\text { Menampilkan Data Waktu } \\
\text { Bus Koridor I }\end{array}$ & $\begin{array}{l}\text { Kendali memilih menu } \\
\text { Koridor I }\end{array}$ & $\begin{array}{l}\text { Sistem menampilkan tabel } \\
\text { data waktu koridor I }\end{array}$ \\
\hline 4 & $\begin{array}{l}\text { Menampilkan Data Waktu } \\
\text { Bus Koridor II }\end{array}$ & $\begin{array}{l}\text { Kendali memilih menu } \\
\text { Koridor II }\end{array}$ & $\begin{array}{l}\text { Sistem menampilkan tabel } \\
\text { data waktu koridor II }\end{array}$ \\
\hline 5 & $\begin{array}{l}\text { Menampilkan Data Status } \\
\text { Bus }\end{array}$ & $\begin{array}{l}\text { Kendali memilih menu } \\
\text { Data Status }\end{array}$ & $\begin{array}{l}\text { Sistem menampilkan tabel } \\
\text { data status bus }\end{array}$ \\
\hline
\end{tabular}

Tabel 4 menampilkan pengujian black box pada kendali. Pengujian ini dilakukan untuk memastikan data yang ditampilkan pada halaman tracking bus, waktu bus dan status bus memberikan informasi yang sesuai dengan kebutuhan petugas kendali.

\section{$5 \quad$ Kesimpulan}

Sistem Pengawasan Operasional Pada Angkutan Publik Trans SARBAGITA diimplementasikan pada dua platform yaitu web dan aplikasi Android. Aplikasi ini menyediakan data yang diperlukan dalam kegiatan operasional Trans SARBAGITA seperti: waktu tempuh, lokasi bus berada, kilometer tempuh, dan status bus yang dibutuhkan untuk membantu proses pengawasan, pengambilan keputusan dan penentuan jadwal keberangkatan bus oleh petugas kendali UPT Trans SARBAGITA, sehingga kegiatan operasional bus Trans SARBAGITA dilakukan dengan efektif dan dapat mewujudkan moda transportasi publik yang terjadwal lebih baik.

\section{Daftar Pustaka}

[1] S. Shinde, V. Nagalwar, and N. Shinde, "Design of E-City Bus Tracking System," International Journal of Engineering Research and Applications, vol. 4, pp. 114-117, 2014.

[2] S. Chandurkar, S. Mugade, S. Sinha, M. Misal, and P. Borekar, "Implementation of real time bus monitoring and passenger information system," International Journal of Scientific and Research Publications, vol. 3, pp. 1-5, 2013.

[3] P. Doshi, P. Jain, and A. Shakwala, "Location based services and integration of google maps in android," ISSN International Journal Of Engineering And Computer Science, vol. 3, pp. 5072-5077, 2014. 
[4] D. Muthumurugesan, S. Nalini, and R. Vinodini, "Smart Way to Track the Location in Android Operating System," IOSR Journal of Computer Engineering (IOSR-JCE) eISSN, vol. 12, pp. 1-6, 2013.

[5] D. Manongga, S. Papilaya, and S. Pandie, "Sistem Informasi Geografis Untuk Perjalanan Wisata Di Kota Semarang," Jurnal Informatika, vol. 10, pp. 1-9, 2010.

[6] I. N. Piarsa, I. G. U. Putra, and A. Sudana, "The Implementation of Tree Method in Geographic Information System of Mother Temple Mapping and its Linkages based on Web," International Journal of Computer Applications, vol. 148, 2016.

[7] L. Gede Sri Handayani, I. N. Piarsa, and K. Suar Wibawa, "Sistem Informasi Geografis Pemetaan Jalan Desa Berbasis Web," Lontar Komputer : Jurnal IImiah Teknologi Informasi, pp. 128-137\%@ 2541-5832, 2015-11-27 2015.

[8] S. Rahayu, I. N. Piarsa, and P. W. Buana, "Sistem Informasi Geografis Pemetaan Daerah Aliran Sungai Berbasis Web," Lontar Komputer : Jurnal Ilmiah Teknologi Informasi, pp. 71-82\%@ 2541-5832, 2016-08-01 2016.

[9] P. W. Buana, I. M. Sukarsa, I. B. G. Purwania, and I. G. B. Y. Prasetya, "Real Time Trans Bus Tracking and Passenger Information System using Hybrid Application Technology," International Journal of Software Engineering and Its Applications, vol. 10, pp. 35-50, 2016.

[10] Dinas Perhubungan Permerintah Provinsi Bali, Trans Sarbagita, dilihat 10 Jaurari 2018, $<$ http://www.dishubinkom.baliprov.go.id/id/ANGKUTAN-UMUM-Trans-SARBAGITA> 